UDC 621.391

\title{
NEW COMPOSITE BARKER CODES IN THE SYNCHRONIZATION SYSTEM OF BROADBAND SIGNALS
}

\author{
Volodymyr V. Maksimov, Ihor A. Khrapovitsky \\ Institute of Telecommunication Systems \\ Igor Sikorsky Kyiv Polytechnic Institute, Kyiv, Ukraine
}

Background. At present, the demand for broadband signals (BBS) is determined by the qualities inherent in these signals, which make it possible to ensure high noise immunity of broadband communication systems (BCS) when transmitting confidential information in an open radio channel, especially in emergency situations. Although the foundations of the BBS theory are well known, the development of wireless communication networks requires constant refinements of theoretical provisions in accordance with new data on methods for constructing Barker code sequences used in wireless communication systems with direct sequence spread spectrum technology.

Objective. The aim of the paper is to study new composite Barker codes as synchronization signals and compare them with known composite codes using simulation.

Methods. Analytical methods of calculation are used, as well as simulation modeling in the MatLab software package.

Results. Simulation modeling was carried out, which confirmed the possibility of using new composite Barker codes as synchronization signals in the BCS.

Conclusions. Modeling in the MatLab software package showed a greater noise immunity of new composite codes to the influence of various modulating sequences of an information signal in comparison with known composite codes.

Keywords: Barker codes; composite Barker codes; autocorrelation function.

\section{Introduction}

Broadband signals (BBS) are used in modern multi-channel code division multiplexing systems (CDMA, WCDMA) [1], in 802.11 family of wireless communication systems with Direct Sequence Spread Spectrum (DSSS) [2], in modern radar systems [3]. In the role of special spreading sequences in WCDMA networks, M-sequences, Gould sequences, Barker sequences can be used, in 802.11 wireless communication systems, the Barker sequence of length 11 is used for spreading the spectrum, in modern radar systems, Barker codes of length 11 and 13 are used.

Of all BBS, the Barker sequences discovered in 1953 have the best correlation characteristics [4]. The value of the maximum lateral emission of their autocorrelation function (ACF) does not exceed $1 / \mathrm{N}$, where $\mathrm{N}$ is the length of the code sequence. There are only 8 known Barker sequences; the maximum sequence length reaches 13 bits. The search for code sequences of length $\mathrm{N}>13$, in which the value of the maximum lateral ACF ejection would not exceed $1 / \mathrm{N}$, is an urgent problem.

In [5], a method was proposed for the formation of composite Barker codes with correlation properties similar to those of the Barker code, namely: the code is formed by multiplying two canonical Barker sequences. One of them (short) is called a generator, and the second, longer one, is called elementary. As a result of multiplying a short sequence by a longer sequence, sequences over 13 bits are obtained. Their main ACF overshoot is equal to the number of bits of the resulting sequence $\mathrm{N}$, and the maximum lateral overshoot into the positive region has values close to 1 . In [6], by forming composite code sequences similarly to the method proposed in [5], 12 sequences with length $\mathrm{N}$ were obtained, equal to 14 (14a, 14b), 21 (21a, 21b), 22 (22a, 22b), 33 (33a, 33b), 49, 77 (77a, 77b), 121, and the excess of the main peak of the ACF over the positive lateral ones, equal to N. In [7], inverse composite Barker codes were proposed, obtained by multiplying a long sequence by a short one, their noise immunity was investigated, and the possibility of their use as sync words in WCDMA networks was shown. In [8], the same composite code sequences are described as in [6], but under the name of "Barker-Volynskaya" codes, and the possibility of their use, both for command transmission and for synchronization, is indicated. It was shown in [9] that the ACF of composite Barker codes, which are formed as scalar products of canonical Barker sequences $[4,10]$, can be written as: 


$$
\begin{aligned}
& R_{\text {comp }}(k)=\frac{1}{m} \sum_{i=0}^{m} c_{\text {comp }}(i) \mathrm{c}_{\text {comp }}(i+k)=\frac{1}{m} \sum_{i=0}^{m} \mathrm{c}_{\text {comp.inv }}(i) \mathrm{c}_{\text {comp.inv }}(i+k)= \\
& =\frac{1}{m} \sum_{i=0}^{m} \mathrm{c}_{\text {comp.mirrored }}(i) \mathrm{c}_{\text {comp.mirrored }}(i+k)=\frac{1}{m} \sum_{i=0}^{m} \mathrm{c}_{\text {comp.inv.mirrored }}(i) \mathrm{c}_{\text {comp.inv.mirrored }}(i+k),(1)
\end{aligned}
$$

where $c_{\text {comp }}(i)$ is a composite Barker sequence, defined as $c_{\text {comp }}(i)=c_{1}(i) c_{2}(i) \ldots c_{\mathrm{n}}(i)$, and $c_{\mathrm{n}}(i)$ take values \pm 1 ; $c_{\text {comp.inv }}(i)=(-1) c_{\text {comp }}(i) ; c_{\text {comp.mirrored }}(i)=c_{\mathrm{n}}(i) c_{\mathrm{n}-1}(i) \ldots c_{1}(i) ; c_{\text {comp.inv.mirrored }}(i)=(-1) c_{\text {comp } / \text { mirrored }}(i)$.

$c_{1}(i) c_{2}(i) \ldots c_{\mathrm{n}}(i)$

It was also shown in [9] that, based on (1), the composite Barker sequences obtained in [6] can be supplemented with inverse, mirror, and inverse mirror composite sequences, which will have the same ACF as the main composite sequence, thereby increasing their number from 12 to 48 . In addition, in [9], four pairs of new composite Barker sequences were obtained that have the same ACF as 77b (the sequence number is taken according to [6]). In [11], based on the technique described in [9], for each of the composite sequences 121, 77a, 49, 33a, 33b, 21a, 21b, 4 pairs of combinations of the main Barker sequences were found, forming a total of 28 new composite sequences having the same autocorrelation function as the original composite sequences. Table 1 shows all 32 pairs of new composite sequences obtained in $[9,11]$.

\begin{tabular}{|c|c|c|}
\hline New № & Option & New composite sequences 121 \\
\hline New 1. & $\begin{array}{l}\text { C11 } 11 \text { A11 } \\
\text { D11 } 11 \text { B } 11\end{array}$ & $\begin{array}{l}-1-1-1+1+1+1-1+1+1-1+1+1+1+1-1-1-1+1-1-1+1-1-1-1-1+1+1+1-1+1+1-1+1-1-1-1+1+1+1- \\
1+1+1-1+1+1+1+1-1-1-1+1-1-1+1-1-1-1-1+1+1+1-1+1+1-1+1-1-1-1+1+1+1-1+1+1-1+1-1-1- \\
1+1+1+1-1+1+1-1+1+1+1+1-1-1-1+1-1-1+1-1+1+1+1-1-1-1+1-1-1+1-1+1+1+1-1-1-1+1-1-1+1-1\end{array}$ \\
\hline New 2. & $\begin{array}{l}\text { C11 x B11 } \\
\text { D11 x A11 }\end{array}$ & $\begin{array}{l}+1+1+1-1-1-1+1-1-1+1-1-1-1-1+1+1+1-1+1+1-1+1+1+1+1-1-1-1+1-1-1+1-1+1+1+1-1-1-1+1-1- \\
1+1-1-1-1-1+1+1+1-1+1+1-1+1+1+1+1-1-1-1+1-1-1+1-1+1+1+1-1-1-1+1-1-1+1-1+1+1+1-1-1- \\
1+1-1-1+1-1-1-1-1+1+1+1-1+1+1-1+1-1-1-1+1+1+1-1+1+1-1+1-1-1-1+1+1+1-1+1+1-1+1\end{array}$ \\
\hline New 3. & $\begin{array}{l}\text { A11 x C11 } \\
\text { B11 x D11 }\end{array}$ & $\begin{array}{l}-1+1-1-1+1-1-1-1+1+1+1-1+1-1-1+1-1-1-1+1+1+1-1+1-1-1+1-1-1-1+1+1+1+1-1+1+1-1+1+1+1- \\
1-1-1+1-1+1+1-1+1+1+1-1-1-1+1-1+1+1-1+1+1+1-1-1-1-1+1-1-1+1-1-1-1+1+1+1+1-1+1+1- \\
1+1+1+1-1-1-1+1-1+1+1-1+1+1+1-1-1-1-1+1-1-1+1-1-1-1+1+1+1+1-1+1+1-1+1+1+1-1-1-1\end{array}$ \\
\hline New 4 & $\begin{array}{l}\text { A11 x D11 } \\
\text { B11 x C11 }\end{array}$ & $\begin{array}{l}+1-1+1+1-1+1+1+1-1-1-1+1-1+1+1-1+1+1+1-1-1-1+1-1+1+1-1+1+1+1-1-1-1-1+1-1-1+1-1-1- \\
1+1+1+1-1+1-1-1+1-1-1-1+1+1+1-1+1-1-1+1-1-1-1+1+1+1+1-1+1+1-1+1+1+1-1-1-1-1+1-1-1+1- \\
1-1-1+1+1+1-1+1-1-1+1-1-1-1+1+1+1+1-1+1+1-1+1+1+1-1-1-1-1+1-1-1+1-1-1-1+1+1+1\end{array}$ \\
\hline № & Option & New composite sequences $77 \mathrm{a}$ \\
\hline New 1. & $\begin{array}{l}\text { C11 } 11 \text { A7 } \\
\text { D11 } \times \text { B7 }\end{array}$ & $\begin{array}{l}-1-1-1+1+1-1+1+1+1+1-1-1+1-1-1-1-1+1+1-1+1-1-1-1+1+1-1+1+1+1+1-1-1+1-1-1-1-1+1+1- \\
1+1-1-1-1+1+1-1+1-1-1-1+1+1-1+1+1+1+1-1-1+1-1+1+1+1-1-1+1-1+1+1+1-1-1+1-1\end{array}$ \\
\hline New 2. & $\begin{array}{l}\text { C11 } \times \text { B7 } \\
\text { D11 } \times \text { A7 }\end{array}$ & $\begin{array}{l}+1+1+1-1-1+1-1-1-1-1+1+1-1+1+1+1+1-1-1+1-1+1+1+1-1-1+1-1-1-1-1+1+1-1+1+1+1+1-1- \\
1+1-1+1+1+1-1-1+1-1+1+1+1-1-1+1-1-1-1-1+1+1-1+1-1-1-1+1+1-1+1-1-1-1+1+1-1+1\end{array}$ \\
\hline New 3. & $\begin{array}{l}\text { A11 } \times \text { C7 } \\
\text { B11 } \times \text { D7 }\end{array}$ & $\begin{array}{l}-1+1-1-1+1+1+1-1+1-1-1+1+1+1-1+1-1-1+1+1+1+1-1+1+1-1-1-1+1-1+1+1-1-1-1+1-1+1+1-1- \\
1-1-1+1-1-1+1+1+1+1-1+1+1-1-1-1+1-1+1+1-1-1-1-1+1-1-1+1+1+1+1-1+1+1-1-1-1\end{array}$ \\
\hline New 4 & $\begin{array}{l}\text { A11 } \times \text { D7 } \\
\text { B11 } \times \text { C7 }\end{array}$ & $\begin{array}{l}+1-1+1+1-1-1-1+1-1+1+1-1-1-1+1-1+1+1-1-1-1-1+1-1-1+1+1+1-1+1-1-1+1+1+1-1+1-1- \\
1+1+1+1+1-1+1+1-1-1-1-1+1-1-1+1+1+1-1+1-1-1+1+1+1+1-1+1+1-1-1-1-1+1-1-1+1+1+1\end{array}$ \\
\hline № & Option & New composite sequences $77 \mathrm{~b}$ \\
\hline New 1. & $\begin{array}{l}\text { C7 } \times \text { A11 } \\
\text { D7 } \times \text { B11 }\end{array}$ & $\begin{array}{l}-1-1-1+1+1+1-1+1+1-1+1+1+1+1-1-1-1+1-1-1+1-1-1-1-1+1+1+1-1+1+1-1+1-1-1-1+1+1+1- \\
1+1+1-1+1+1+1+1-1-1-1+1-1-1+1-1+1+1+1-1-1-1+1-1-1+1-1+1+1+1-1-1-1+1-1-1+1-1\end{array}$ \\
\hline New 2. & $\begin{array}{l}\text { C7 } \times \text { B11 } \\
\text { D7 } \times \text { A11 }\end{array}$ & $\begin{array}{l}+1+1+1-1-1-1+1-1-1+1-1-1-1-1+1+1+1-1+1+1-1+1+1+1+1-1-1-1+1-1-1+1-1+1+1+1-1-1-1+1-1- \\
1+1-1-1-1-1+1+1+1-1+1+1-1+1-1-1-1+1+1+1-1+1+1-1+1-1-1-1+1+1+1-1+1+1-1+1\end{array}$ \\
\hline New 3. & $\begin{array}{l}\mathrm{A} 7 \times \mathrm{C} 11 \\
\mathrm{~B} 7 \times \mathrm{D} 11\end{array}$ & $\begin{array}{l}-1+1-1-1+1-1-1-1+1+1+1-1+1-1-1+1-1-1-1+1+1+1-1+1-1-1+1-1-1-1+1+1+1+1-1+1+1-1+1+1+1- \\
1-1-1+1-1+1+1-1+1+1+1-1-1-1-1+1-1-1+1-1-1-1+1+1+1+1-1+1+1-1+1+1+1-1-1-1\end{array}$ \\
\hline New 4 & $\begin{array}{l}\mathrm{A} 7 \times \mathrm{D} 11 \\
\mathrm{~B} 7 \times \mathrm{C} 11\end{array}$ & $\begin{array}{l}+1-1+1+1-1+1+1+1-1-1-1+1-1+1+1-1+1+1+1-1-1-1+1-1+1+1-1+1+1+1-1-1-1-1+1-1-1+1-1-1- \\
1+1+1+1-1+1-1-1+1-1-1-1+1+1+1+1-1+1+1-1+1+1+1-1-1-1-1+1-1-1+1-1-1-1+1+1+1\end{array}$ \\
\hline № & Option & New composite sequences 49 \\
\hline New 1. & C7 $x$ A7 & $-1-1-1+1+1-1+1+1+1+1-1-1+1-1-1-1-1+1+1-1+1-1-1-1+1+1-1+1+1+1+1-1-1+1-1+1+1+1-1-1+1-$ \\
\hline
\end{tabular}

Table 1. New composite sequences 


\begin{tabular}{|c|c|c|}
\hline & D7 x B7 & $1+1+1+1-1-1+1-1$ \\
\hline New 2. & $\begin{array}{l}\mathrm{D} 7 \times \mathrm{A} 7 \\
\mathrm{C} 7 \times \mathrm{B} 7\end{array}$ & $\begin{array}{l}+1+1+1-1-1+1-1-1-1-1+1+1-1+1+1+1+1-1-1+1-1+1+1+1-1-1+1-1-1-1-1+1+1-1+1-1-1-1+1+1- \\
1+1-1-1-1+1+1-1+1\end{array}$ \\
\hline New 3. & $\begin{array}{l}\text { A7 } \times \text { C7 } \\
\text { B7 } \times \text { D7 }\end{array}$ & $\begin{array}{l}-1+1-1-1+1+1+1-1+1-1-1+1+1+1-1+1-1-1+1+1+1+1-1+1+1-1-1-1+1-1+1+1-1-1-1-1+1-1- \\
1+1+1+1+1-1+1+1-1-1-1\end{array}$ \\
\hline New 4 & $\begin{array}{l}\text { B7 x C7 } \\
\text { A7 x D7 }\end{array}$ & $\begin{array}{l}+1-1+1+1-1-1-1+1-1+1+1-1-1-1+1-1+1+1-1-1-1-1+1-1-1+1+1+1-1+1-1-1+1+1+1+1-1+1+1-1-1-1- \\
1+1-1-1+1+1+1\end{array}$ \\
\hline № & Option & New composite sequences 33a \\
\hline New 1. & $\begin{array}{l}\text { C11 x A3 } \\
\text { D11 x B3 }\end{array}$ & $-1-1+1+1+1-1-1-1+1-1-1+1+1+1-1-1-1+1-1-1+1-1-1+1+1+1-1+1+1-1+1+1-1$ \\
\hline New 2. & $\begin{array}{l}\mathrm{D} 11 \times \mathrm{A} 3 \\
\mathrm{C} 11 \times \mathrm{B} 3\end{array}$ & $+1+1-1-1-1+1+1+1-1+1+1-1-1-1+1+1+1-1+1+1-1+1+1-1-1-1+1-1-1+1-1-1+1$ \\
\hline New 3. & $\begin{array}{l}\mathrm{A} 11 \times \mathrm{C} 3 \\
\mathrm{~B} 11 \times \mathrm{D} 3\end{array}$ & $-1+1+1-1+1+1-1+1+1+1-1-1+1-1-1+1-1-1-1+1+1+1-1-1+1-1-1-1+1+1+1-1-1$ \\
\hline New 4 & $\begin{array}{l}\text { B11 x } 3 \\
\text { A11 x D3 }\end{array}$ & $+1-1-1+1-1-1+1-1-1-1+1+1-1+1+1-1+1+1+1-1-1-1+1+1-1+1+1+1-1-1-1+1+1$ \\
\hline № & Option & New composite sequences $33 \mathrm{~b}$ \\
\hline New 1. & $\begin{array}{l}\text { C3 } \times \text { A11 } \\
\text { D3 } \times \text { B } 11\end{array}$ & $-1-1-1+1+1+1-1+1+1-1+1+1+1+1-1-1-1+1-1-1+1-1+1+1+1-1-1-1+1-1-1+1-1$ \\
\hline New 2. & $\begin{array}{l}\mathrm{D} 3 \times \mathrm{A} 11 \\
\mathrm{C} 3 \mathrm{~B} 11\end{array}$ & $+1+1+1-1-1-1+1-1-1+1-1-1-1-1+1+1+1-1+1+1-1+1-1-1-1+1+1+1-1+1+1-1+1$ \\
\hline New 3. & $\begin{array}{l}\text { A3 } x \text { C11 } \\
\text { B3 } x \text { D11 }\end{array}$ & $-1+1-1-1+1-1-1-1+1+1+1-1+1-1-1+1-1-1-1+1+1+1+1-1+1+1-1+1+1+1-1-1-1$ \\
\hline New 4 & $\begin{array}{l}\text { B3 } \times \text { C11 } \\
\text { A3 } \times \text { D11 }\end{array}$ & $+1-1+1+1-1+1+1+1-1-1-1+1-1+1+1-1+1+1+1-1-1-1-1+1-1-1+1-1-1-1+1+1+1$ \\
\hline № & Option & New composite sequences 21a \\
\hline New 1. & $\begin{array}{l}\text { C7 x A3 } \\
\text { D7 x B3 }\end{array}$ & $-1-1+1+1+1-1-1-1+1-1-1+1+1+1-1+1+1-1+1+1-1$ \\
\hline New 2. & $\begin{array}{l}\mathrm{D} 7 \times \mathrm{A} 3 \\
\mathrm{C} 7 \times \mathrm{B} 3\end{array}$ & $+1+1-1-1-1+1+1+1-1+1+1-1-1-1+1-1-1+1-1-1+1$ \\
\hline New 3. & $\begin{array}{l}\mathrm{A} 7 \times \mathrm{C} 3 \\
\mathrm{~B} 7 \times \mathrm{D} 3\end{array}$ & $-1+1+1-1+1+1-1+1+1+1-1-1+1-1-1-1+1+1+1-1-1$ \\
\hline New 4 & $\begin{array}{l}\text { B7 x C3 } \\
\text { A7 x D } 3\end{array}$ & $+1-1-1+1-1-1+1-1-1-1+1+1-1+1+1+1-1-1-1+1+1$ \\
\hline № & Option & New composite sequences $21 \mathrm{~b}$ \\
\hline New 1. & $\begin{array}{l}\text { C3 } \times \text { A7 } \\
\text { D3 } \times \text { B } 7\end{array}$ & $-1-1-1+1+1-1+1+1+1+1-1-1+1-1+1+1+1-1-1+1-1$ \\
\hline New 2. & $\begin{array}{l}\text { D3 } \times \text { A7 } \\
\text { C3 } \times \text { B7 }\end{array}$ & $+1+1+1-1-1+1-1-1-1-1+1+1-1+1-1-1-1+1+1-1+1$ \\
\hline New 3. & $\begin{array}{l}\text { A3 x C7 } \\
\text { B3 } \times \text { D7 }\end{array}$ & $-1+1-1-1+1+1+1-1+1-1-1+1+1+1+1-1+1+1-1-1-1$ \\
\hline New 4 & $\begin{array}{l}\mathrm{B} 3 \times \mathrm{C} 7 \\
\mathrm{~A} 3 \times \mathrm{D} 7\end{array}$ & $+1-1+1+1-1-1-1+1-1+1+1-1-1-1-1+1-1-1+1+1+1$ \\
\hline
\end{tabular}

The aim of this work is to study the possibility of using the new composite Barker codes obtained in $[9,11]$ as synchronization pulses for BBS.

\section{Modeling the NLS reception mode}

The mode of receiving and extracting synchronization pulses (SI) of BBS without dividing the channels for receiving the sync pulse and the channel for receiving the information sequence occurs at the initial stage of receiving BBS, i.e. when SI are not yet detected, they are not synchronized by the PLL with the transmitting signals and do not distribute the received BBS along the paths. In this case, information signals are a hindrance to the selection of SI. The level of such interference depends on the cross-correlation of the code sequences used both for generating the SI code and for spreading the spectrum of the information sequence. To determine the possibility of using new composite Barker codes as SI, it is necessary, on the one hand, to compare them with the well-known 
composite Barker codes, and, on the other hand, to choose as information signals those that would create the greatest level of interference for them. As the known composite codes, we select the original composite Barker-Volynskaya codes [8], as the informational ones - the embedded Barker codes, which have the same generating Barker code as the known and new composite codes.

The structures (methods of formation) of new composite sequences New1 ... New4 are the same and can be written as Ao - the length of the generatrix of the canonical Barker sequence (SB), Bo - the length of the generatrix of the inverse $\mathrm{SB}, \mathrm{Co}-$ the length of the generatrix of the mirror SB, Do - the length of the generatrix of the inverse-mirror SB, Am is the length of the modulating canonical $\mathrm{SB}, \mathrm{Bm}$ is the length of the modulating inverse $\mathrm{SB}, \mathrm{Cm}$ is the length of the modulating mirrored $\mathrm{SB}, \mathrm{Dm}$ is the length of the modulating inverse-mirrored SB. It can be seen that all new pairs of composite sequences New1 and New3, New2 and New4 are mirrored with respect to each other, and new pairs of composite sequences New1 and New2, New3 and New4 are inverted with respect to each other.

The MATLAB R2015B program was used for simulation. The diagram of the model (Fig. 1) consists of the following main functional units: a BBS shaper; receiver of sync signals; switches of operating modes.
The shaper consists of:

- generator of composite Barker code (CCB). Composite Barker code is transmitted as a sync pulse;

- two generators of the Barker code (Barker Code Generator), one of which creates an information sequence, and the second modulates the information pulse with direct or inverse high-speed Barker code, forming a BBS;

- pulse generator (Pulse Generator) with a duty cycle of $10 \%$. Synchronization pulse (10\% of the time) and informational BBS ( $90 \%$ of the time) are sent to the output of the shaper via controlled switches.

The sync receiver consists of:

- sync signal extractor (a);

- control schemes for the limiting threshold level (b); - error detector (c).

The mode switch allows you to explore the operation of the model in two different modes:

- without dividing the received BBS by channels for receiving sync signals and information signals;

- with division of the received BBS along the channels for receiving synchrosignals and information signals.

The separation of the BBS along the paths is controlled by a pulse generator (Pulse Generator2) with a duty cycle of $10 \%$, similar to the generator that forms the BBS.

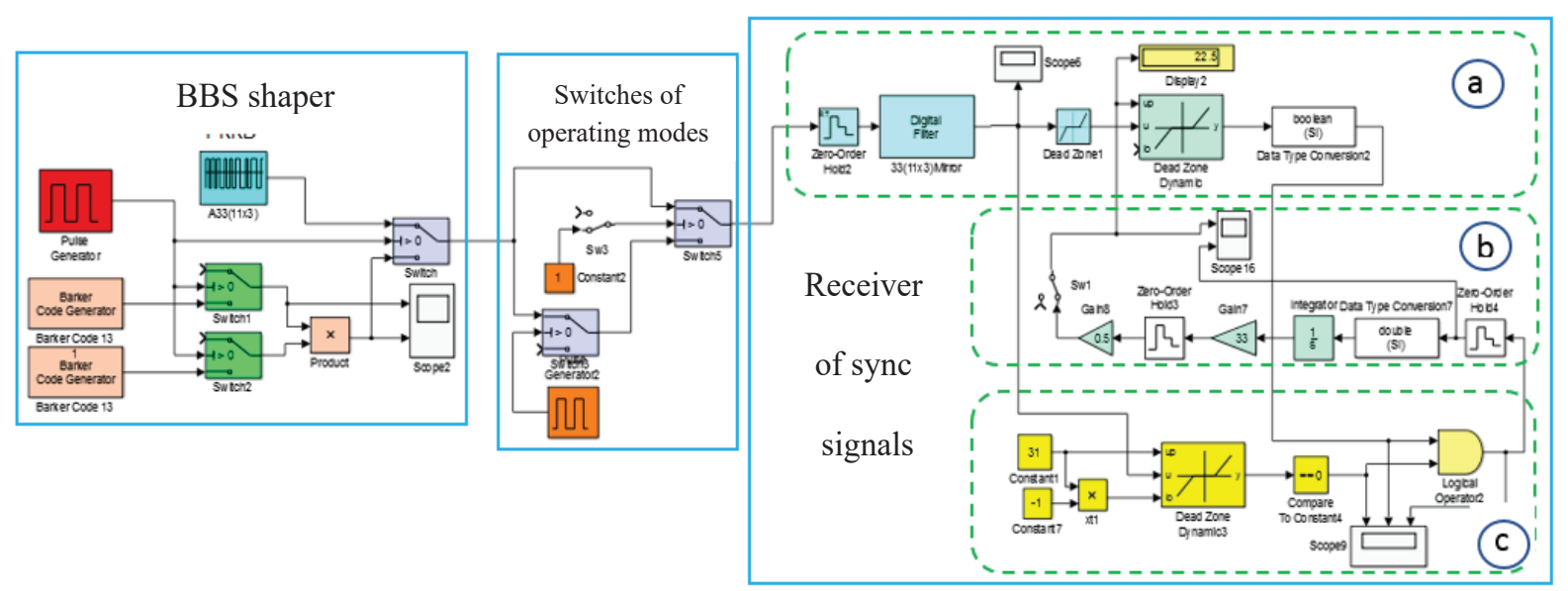

Fig. 1 Model of the receiving-transmitting channel of the NLS

The model automatically determines the threshold level $\mathrm{L}_{0}$ when an error-free detection of synchronization pulses is achieved. Loss in the selection of the peak of the synchronization pulse is defined as

$$
\mathrm{P}(\%)=\mathrm{L}_{0} / \mathrm{A}
$$

where $\mathrm{A}$ is the amplitude of the synchronization pulse equal to the length of the composite code.

The efficiency of using new composite codes was estimated by the parameter

$$
\Delta \mathrm{P}(\%)=\mathrm{P}_{\mathrm{BV}}(\%)-\mathrm{P}(\%)
$$

where $\mathrm{P}_{\mathrm{BV}}(\%)$ is the sync pulse peak extraction loss when using composite Barker-Volynskaya codes.

Testing was carried out in the "no path separation" mode for composite codes 121 (11x11), 77a (11x7), 77b (7x11), 49 (7x7), 33a (11x3), 33b (3x11), 21a (7x3) and 21b (3x7)).

\section{Simulation results}


Below, as an illustration, in Fig. 2 shows the oscillograms of the selection of the original BarkerVolynskaya 77 a (11x7) sync code and four new $11 \times 7$ sync codes with embedded 11x11 Barker codes (information BBS), as well as the corresponding $\mathrm{L}_{0}$, $\mathrm{P}_{\mathrm{BV}}(\%), \mathrm{P}(\%)$ and the efficiency of using new composite codes $\Delta \mathrm{P}(\%)$. Table 2 shows the results of testing the original and new sync codes.

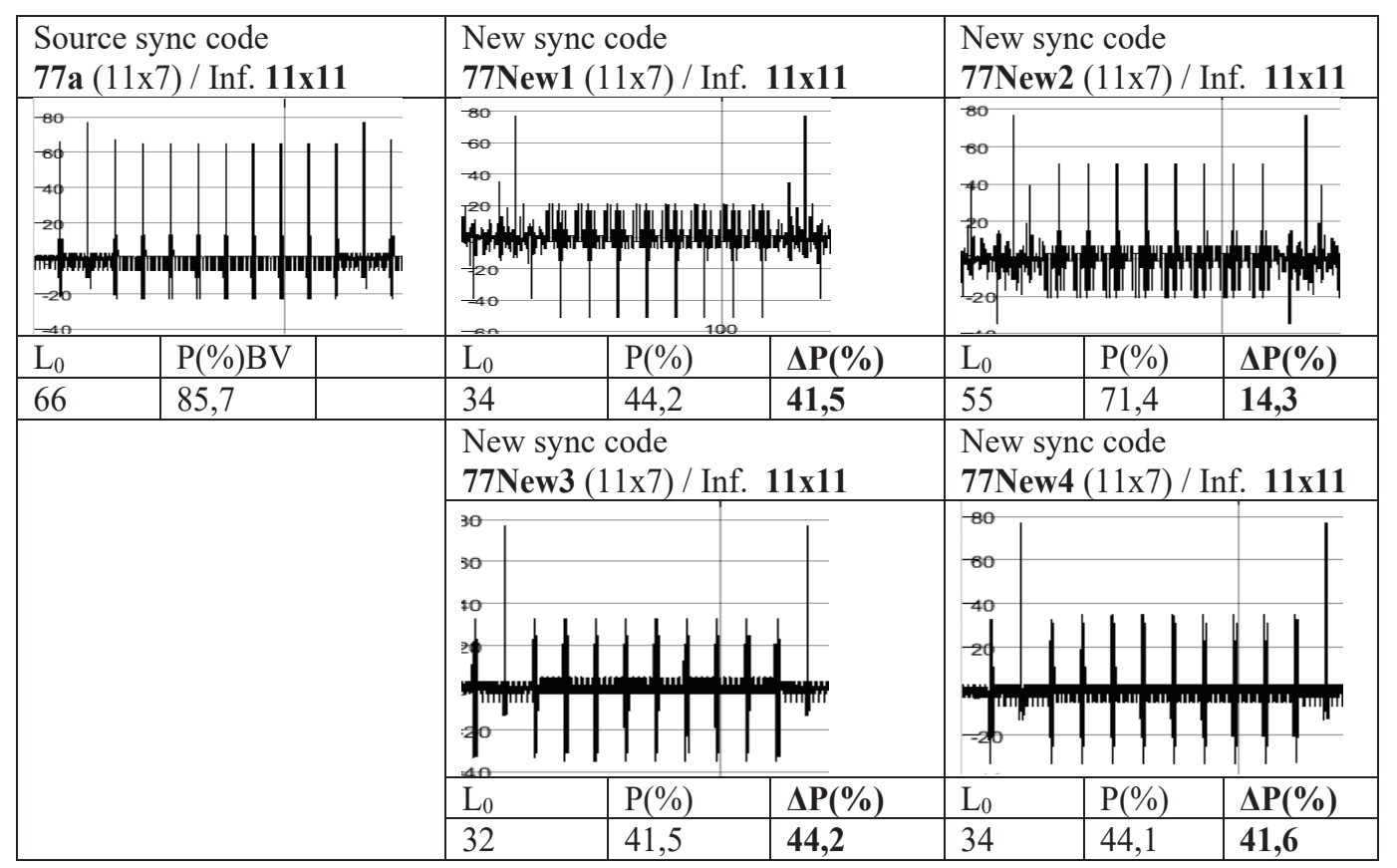

Fig. 2. Oscillograms of sync pulse extraction

Table 2. Test results for the original and new sync codes.

\begin{tabular}{|c|c|c|c|c|c|}
\hline \multirow{8}{*}{$\begin{array}{l}\text { Information } \\
\text { code } \\
11 \times 11\end{array}$} & Barker $\backslash$ Volynskaya code & New1 & New2 & New3 & New4 \\
\hline & \multicolumn{5}{|c|}{ Composite code 121(11x11) } \\
\hline & A11xA11 & C11 x A11 & $\mathrm{C} 11 \times \mathrm{B} 11$ & $\mathrm{~A} 11 \times \mathrm{C} 11$ & A11 x D11 \\
\hline & & $\mathrm{D} 11 \times \mathrm{B} 11$ & D11 x A11 & B11 x D11 & $\mathrm{B} 11 \times \mathrm{C} 11$ \\
\hline & \multicolumn{5}{|c|}{ Loss when highlighting the peak of the synchronization pulse, $\mathrm{P}(\%)$} \\
\hline & 100 & 44,6 & 81 & 56,2 & 54,5 \\
\hline & \multicolumn{5}{|c|}{ Efficiency of using new composite codes $\Delta \mathrm{P}(\%)$} \\
\hline & - & 55,4 & 19 & 43,8 & 45,5 \\
\hline \multirow{7}{*}{$\begin{array}{l}\text { Information } \\
\text { code } \\
11 \times 11\end{array}$} & \multicolumn{5}{|c|}{ Composite code $77 \mathrm{a}(11 \times 7)$} \\
\hline & A11xA7 & C $11 \times$ A 7 & C $11 \times$ B 7 & A $11 \times$ C 7 & A $11 \times$ D 7 \\
\hline & & D $11 \times$ B 7 & D $11 \times$ A 7 & B $11 \times$ D 7 & B $11 \times C 7$ \\
\hline & \multicolumn{5}{|c|}{ Loss when highlighting the peak of the synchronization pulse, $\mathrm{P}(\%)$} \\
\hline & 85,7 & 41,2 & 65 & 41,2 & 41,2 \\
\hline & \multicolumn{5}{|c|}{ Efficiency of using new composite codes $\Delta \mathrm{P}(\%)$} \\
\hline & - & 41,5 & 14,3 & 44,2 & 41,6 \\
\hline \multirow{7}{*}{$\begin{array}{l}\text { Information } \\
\text { code } \\
7 \times 11\end{array}$} & \multicolumn{5}{|c|}{ Composite code $77 b(7 \times 11)$} \\
\hline & A7xA11 & C7 x A11 & C7 x B11 & A7 x C11 & A7 x D11 \\
\hline & & $\mathrm{D} 7 \times \mathrm{B} 11$ & D7 x A11 & B7 x D11 & $\mathrm{B} 7 \mathrm{x} \mathrm{C11}$ \\
\hline & \multicolumn{5}{|c|}{ Loss when highlighting the peak of the synchronization pulse, $\mathrm{P}(\%)$} \\
\hline & 100 & 41,6 & 70,1 & 57,1 & 55,5 \\
\hline & \multicolumn{5}{|c|}{ Efficiency of using new composite codes $\Delta \mathrm{P}(\%)$} \\
\hline & - & 58,4 & 29,9 & 42,9 & 44,5 \\
\hline \multirow{5}{*}{$\begin{array}{l}\text { Information } \\
\text { code } \\
7 \times 11\end{array}$} & \multicolumn{5}{|c|}{ Composite code 49(7x7) } \\
\hline & A7xA7 & $\mathrm{C} 7 \times \mathrm{A} 7$ & $\mathrm{C} 7 \times \mathrm{B} 7$ & $\mathrm{~A} 7 \times \mathrm{C} 7$ & A7 x D7 \\
\hline & & D7 x B7 & D7 x A7 & B7 x D7 & $\mathrm{B} 7 \times \mathrm{C} 7$ \\
\hline & \multicolumn{5}{|c|}{ Loss when highlighting the peak of the synchronization pulse, $\mathrm{P}(\%)$} \\
\hline & 85,7 & 40,8 & 53,1 & 40,8 & 44,9 \\
\hline
\end{tabular}




\begin{tabular}{|c|c|c|c|c|c|}
\hline & \multicolumn{5}{|c|}{ Efficiency of using new composite codes $\Delta \mathrm{P}(\%)$} \\
\hline & - & 44,9 & 32,6 & 44,9 & 40,8 \\
\hline \multirow{7}{*}{$\begin{array}{l}\text { Information } \\
\text { code } \\
11 \times 11\end{array}$} & \multicolumn{5}{|c|}{ Composite code $33 \mathrm{a}(11 \times 3)$} \\
\hline & A11xA3 & C $11 \times \mathrm{A} 3$ & $\mathrm{C} 11 \times \mathrm{B} 3$ & A $11 \times C 3$ & A $11 \times$ D3 \\
\hline & & D $11 \times$ B 3 & D $11 \times$ A 3 & B $11 \times$ D 3 & B $11 \times C 3$ \\
\hline & \multicolumn{5}{|c|}{ Loss when highlighting the peak of the synchronization pulse, $\mathrm{P}(\%)$} \\
\hline & 66,7 & 54,5 & 60,6 & 30,3 & 100 \\
\hline & \multicolumn{5}{|c|}{ Efficiency of using new composite codes $\Delta \mathrm{P}(\%)$} \\
\hline & - & 12,2 & 6,1 & 36,4 & $-33,3$ \\
\hline \multirow{7}{*}{$\begin{array}{l}\text { Information } \\
\text { code } \\
3 \times 11\end{array}$} & \multicolumn{5}{|c|}{ Composite code $33 \mathrm{~b}(3 \times 11)$} \\
\hline & A3xA11 & C $3 \times \mathrm{A} 11$ & C3 x B 11 & A $3 \times$ C 11 & A $3 \times$ D11 \\
\hline & & D $3 \times$ B 11 & D $3 \times$ A 11 & B $3 \times$ D 11 & $\mathrm{~B} 3 \times \mathrm{C} 11$ \\
\hline & \multicolumn{5}{|c|}{ Loss when highlighting the peak of the synchronization pulse, $\mathrm{P}(\%)$} \\
\hline & 100 & 100 & 30,3 & 63,6 & 54,5 \\
\hline & \multicolumn{5}{|c|}{ Efficiency of using new composite codes $\Delta \mathrm{P}(\%)$} \\
\hline & - & 0 & 69,7 & 36,4 & 45,5 \\
\hline \multirow{7}{*}{$\begin{array}{l}\text { Information } \\
\text { code } \\
7 \times 11\end{array}$} & \multicolumn{5}{|c|}{ Composite code $21 \mathrm{a}(7 \times 3)$} \\
\hline & A7xA3 & $\mathrm{C} 7 \times \mathrm{A} 3$ & C7 x B 3 & A $7 \times$ C 3 & A $7 \times$ D3 \\
\hline & & D 7 x B 3 & D 7 x A 3 & B 7x D 3 & B7 x C 3 \\
\hline & \multicolumn{5}{|c|}{ Loss when highlighting the peak of the synchronization pulse, $\mathrm{P}(\%)$} \\
\hline & 66,6 & 47,6 & 57,1 & 28,6 & 100 \\
\hline & \multicolumn{5}{|c|}{ Efficiency of using new composite codes $\Delta \mathrm{P}(\%)$} \\
\hline & - & 19 & 9,5 & 38 & $-33,4$ \\
\hline \multirow{7}{*}{$\begin{array}{l}\text { Information } \\
\text { code } \\
3 \times 11\end{array}$} & \multicolumn{5}{|c|}{ Composite code $21 \mathrm{~b}(3 \times 7)$} \\
\hline & A3xA7 & C3 x A7 & C3 x B 7 & $\mathrm{~A} 3 \times \mathrm{C} 7$ & A $7 \times$ D7 \\
\hline & & D3 x B7 & D3 x A 7 & B 3x D7 & $\mathrm{B} 7 \mathrm{x}$ C7 \\
\hline & \multicolumn{5}{|c|}{ Loss when highlighting the peak of the synchronization pulse, $\mathrm{P}(\%)$} \\
\hline & 85,7 & 76,2 & 57,1 & 38 & 47,6 \\
\hline & \multicolumn{5}{|c|}{ Efficiency of using new composite codes $\Delta \mathrm{P}(\%)$} \\
\hline & - & 9,5 & 28,6 & 47,7 & 38,1 \\
\hline
\end{tabular}

\section{Conclusions}

1. Analysis of the simulation results shows that the new composite Barker sequences in the considered cases of use as sync signals are more efficient than the original Barker-Volynskaya codes, namely:

- New1, New2, New3 and New4 (121 (11x11), 77a (11x7), 77b (7x11), 49 (7x7)) by (14.3 - 58.4)\%;

- New1, New2, New3 (33a (11x3)) by $(6.1-36.4) \%$;

- New2, New3 and New4 (33b (3x11)) by (36.4 69.7)\%;

- New1, New2, New3 (21a (7x3)) by (9.5 - 38)\%;

- New1, New2, New3 and New4 (21b (3x7)) by (9.5 47.7)\%;

2. New composite Barker sequences New2 and New3 (121 (11x11), 77a (11x7), 77b (7x11), 49 (7x7), 33a (11x3), 33b (3x11), 21a (7x3), 21b (3x7)) in all considered cases of use as clock signals more efficient than the original Barker-Volynskaya codes by $(6.1-63.6) \%$.

\section{References}

1. Sklar B. Digital Communication. Theoretical basis and practical application. - M.: Publishing house "Williams", 2003. - 1104 p.

2. Shakhnovich I.V. Modern technologies of wireless communication. M., Technosphere, 2006. 288 p. (in Russian)

3. Sergeev M.B., Nenashev V.A., Sergeev A.M. Nested code sequences of Barker-Mersenne-Raghavarao. Information and control systems, 2019, No. 3, pp. 71-81. (in Russian)

4. Barker, R. H. "Group Synchronizing of Binary Digital Sequences". Communication Theory. London: Butterworth. P. 273-287.

5. Banket V.L., Tokar' M.S. "Composite Barker Codes" // Digital Technologies No. 2, 2007. pp.8-17. (in Russian) 6. Volynskaya A.V. Results of mathematical modeling of the code sequence searching process with given correlation properties // USURT Herald: Scientific-technological journal. - Ekaterinburg: USURT, 2009. - No. 3-4. - pp. 64 71. (in Russian)

7. Maksimov V.V., Chuprina R.S. Inverse composite Barker codes // Scientific notes UNIIS, №1 (21), 2012 - pp. 71-76. (in Russian) 
8. Volynskaya A.V., Kalinin P.M. New noise-immune signals for an intelligent telemechanics channel // Fundamental Research №11, 2012. - pp. 922-926. (in Russian)

9. Maksymov V., Khrapovitsky I. Research of composite Barker codes // The scientific heritage, № 48 (2020), P.1, pp. $15-22$.
10. Baskakov S.I. Radiotechnical circuits and signals: Textbook. - M. Higher. school, 1983. - 536 p. (in Russian) 11. Maksimov V.V., Khrapovitsky I.A. New composite barker codes // The scientific heritage, № 49 (2020), P.1, pp. 29-35.

Максимов В.В., Храповицький I.A.

Нові композитні коди баркера в системі синхронізації широкосмугових сигналів

Проблематика. В даний час затребуваність в широкосмугових сигналах (ШСС) визначають властиві цим сигналам якості, які дозволяють забезпечувати високу перешкодозахищеність широкосмугових систем зв'язку (ШСЗ) при передачі конфіденційної інформації у відкритому радіоканалі, особливо в умовах надзвичайних ситуацій. Хоча основи теорії ШСС добре відомі, проте розвиток мереж бездротового зв'язку вимагає постійних уточнень теоретичних положень відповідно до нових даних про способи побудови кодових послідовностей Баркера, які використовуються в системах бездротового зв'язку з технологією розширення спектра методом прямої послідовності.

Мета. Метою роботи є дослідження нових композитних кодів Баркера в якості сигналів синхронізації і порівняння їх з відомими композитними кодами за допомогою моделювання.

Методи. Використовуються аналітичні методи розрахунку, а також імітаційне моделювання в програмному пакеті MatLab.

Результати. Проведено імітаційне моделювання, яке підтвердило можливість використання нових композитних кодів Баркера в якості сигналів синхронізації в ШСЗ.

Висновки. Моделювання в програмному пакеті MatLab показало більшу стійкість нових композитних кодів до впливу різних модулюючих послідовностей інформаційного сигналу в порівнянні з відомими композитними кодами.

Ключові слова: коди Баркера; композитні коди Баркера; автокореляційна функція.

\section{Максимов В.В., Храповицкий И.А.}

Новые композитные коды баркера в системе синхронізации широкополосных сигналов

Проблематика. В настоящее время востребованность в широкополосных сигналах (ШПС) определяют присущие этим сигналам качества, которые позволяют обеспечивать высокую помехозащищенность широкополосных систем связи (ШСС) при передаче конфиденциальной информации в открытом радиоканале, особенно в условиях чрезвычайных ситуаций. Хотя основы теории ШПС хорошо известны, однако развитие сетей беспроводной связи требует постоянных уточнений теоретических положений в соответствии с новыми данными о способах построения кодовых последовательностей Баркера, используемых в системах беспроводной связи с технологией расширения спектра методом прямой последовательности.

Цель. Целью работы является исследование новых композитных кодов Баркера в качестве сигналов синхронизации и сравнение их с известными композитными кодами с помощью моделирования.

Методы. Используются аналитические методы расчета, а также имитационное моделирование в программном пакете MatLab.

Результаты. Проведено имитационное моделирование, которое подтвердило возможность использования новых композитных кодов Баркера в качестве сигналов синхронизации в ШСС.

Выводы. Моделирование в программном пакете MatLab показало большую помехоустойчивость новых композитных кодов к влиянию различных модулирующих последовательностей информационного сигнала по сравнению с известными композитными кодами.

Ключевые слова: коды Баркера; композитные коды Баркера; автокорреляционная функция. 